\title{
Consensus among experts on healthy eating and diet quality index
}

\author{
Consenso entre especialistas sobre alimentação saudável e índice de \\ qualidade da dieta
}

Simone dos Anjos Caivano (https://orcid.org/0000-0002-3035-9888) ${ }^{1}$

Semíramis Martins Álvares Domene (https://orcid.org/0000-0003-3003-2153) ${ }^{2}$
${ }^{1}$ Universidade

Metropolitana de Santos.

Av. Conselheiro Nébias 536,

Encruzilhada. 11045-002

Santos SP Brasil.

simone.caivano@

hotmail.com

${ }^{2}$ Departamento de Políticas

Públicas e Saúde Coletiva,

Universidade Federal de São

Paulo. Santos SP Brasil.
Abstract The article aims to achieve a consensus about Healthy Eating and Diet Quality Index to enable a validation study on the Diet Quality Index. Experts were identified among authors of articles published from 2010 to 2015 that presented the key worlds healthy eating index and diet quality index. The query was carried out by combining the Delphi technique with the Likert method. To determine a consensus, at least three of the following criteria had to be met: minimum score in each statement $(\geq 3,00)$; standard deviation $(<1,5)$; frequency of agreement $(\geq 51 \%)$ and differences between interquartile ranges $(<$ 1,0). Topics regarding Highly palatable foods, oilseeds, and Meat and eggs did not arrived at a consensus in the first round. Experts proposed new themes: Gluten, Meal frequency, Alcohol consumption, and Including nutrients in the diet quality index. Although quality and risk markers in diet are periodically studied, it was only possible to reach consensus on subjects such as fruits, vegetables, milk and dairy products, legumes, and oilseeds as quality markers after theoretical justification. Processed and ready-to-eat foods, highly palatable foods, excessive sweets and fats, and alcohol were readily identified as risk factors.

Key words Healthy eating, Index, Diet quality index, Consensus
Resumo $O$ objetivo do artigo é elaborar um consenso sobre Alimentação Saudável e Indice de Qualidade da Dieta (IQD) para subsidiar estudo de validação do IQD. Os especialistas foram identificados entre autores de artigos publicados entre 2010 e 2015 com os unitermos healthy eating index $e$ diet quality index. A consulta foi feita por meio da técnica Delphi e do método Likert. Para definição do consenso se considerou o atendimento a pelo menos três critérios: pontuação mínima em cada asserção $(\geq 3,00)$; desvio padrão $(\leq 1,5)$; frequência das respostas concordantes $(\geq 51 \%) e$ diferença de intervalo interquartil $(\leq$ 1,0). Os temas Alimentos altamente palatáveis, Oleaginosas $e$ Carnes e ovos não alcançaram o consenso na primeira rodada. Os especialistas propuseram novos temas: Glúten, Fracionamento das refeições, Consumo de álcool $e$ Inserção de nutrientes no IQD. Embora os marcadores de qualidade e de risco na alimentação sejam estudados periodicamente, só foi possivel estabelecer consenso sobre temas como frutas, hortaliças, leite e derivados, leguminosas e oleaginosas como marcadores de qualidade após fundamentação teórica. Os alimentos processados e prontos para consumo, alimentos altamente palatáveis, doces e gorduras em excesso, e álcool foram prontamente identificados como de risco.

Palavras-chave Alimentação saudável, Índice, Índice de qualidade da dieta, Consenso 


\section{Introduction}

Non-communicable chronic diseases (NCD) are in the fifth place of the major death risks in the world ${ }^{1}$. About $30 \%$ of the global population is overweight, and it is possible this number will grow to up to $50 \%$ in $2030^{2}$. In Brazil, $50.1 \%$ of the population is overweight and obesity reaches $12.4 \%$ of the adults ${ }^{3}$. These data arise from lifestyles that are out of balance with health and eating habits, being one of the main factors collaborating to the increase and prevention of $\mathrm{NCDs}^{1,4}$.

Food guides offer orientations to promote healthy changes in the dietary intake of the population ${ }^{5}$. In 2006, the Food Guide for the Brazilian Population (GAPB - Guia Alimentar para a População Brasileira) was published, which classified foods into groups according to the adapted food pyramid of $1999^{6}$. Its new edition prescinds from such logic and conceptualizes quality according to the foods' processing ${ }^{5}$.

Indexes to assess diet quality have been proposed, in line with Food Guides, to enable preventing NCD and care situations ${ }^{7}$. The Healthy Eating Index $(H E I)^{8}$ was built from the recommendations for the American population and influenced, in Brazil, the proposition of the Revised Diet Quality Index (DQI-R) ${ }^{9}$, adjusted for the food groups in the Adapted Food Pyramid .

In 2013, the Diet Quality index in association with the Digital Food Guide (DQI-DFG) was published ${ }^{10}$, based on guidelines of the Public Health School of the University of Harvard ${ }^{11}$ and adjusted for the eating habits of the Brazilian population. It was devised in a design that is in line with the mains principles of the current GAPB $^{5}$ : it is based on food, not in nutrients, without disregarding the relevance of nutritional quotas; prioritizes fresh or minimally processed foods and indicates the importance of consuming less processed and ultra-processed foods; aliments are classified into groups by similarity of nutritional composition and according to the evidence of implications of their regular intake over health ${ }^{10}$.

Considering the existence of particular characteristics on the Brazilian diet, including the importance of beans as a diet quality marker, this study aims to establish a consensus on Healthy Eating and Diet Quality Index in a national perspective by querying researchers with experience on the subject. The result of the consensus described in this work will base a validation study on the DQI-DFG content ${ }^{10}$.

\section{Methods}

Research tool. Topics considered in the construction of the expert query instrument correspond to components and food groups included in the DQI-DFG (Table 1) ${ }^{10}$. The theoretical foundation for devising the statements was gathered from a systematic study on field publications from 2007 to the construction of the first version of DQI-DFG, published in 2009. Conclusions and recommendations of studies on the relationship between diet and disease prevention ${ }^{12-16}$, national and international research on Diet Quality Indexes (DQI) and healthy eating ${ }^{7,10,16,17}$, and official documents of international and national organizations with the same purpose ${ }^{5,18-21}$ were embodied into this study.

The instrument comprised two analysis dimensions consisting of 21 statements and one open question (We would like you to please indicate themes and/or issues that were not addressed herein and that you consider to be important for the arriving at a consensus on Healthy Eating and Diet Quality Index) - Table 2. Equivalent statements were intended to probe the answer consistency:

Dimension 1 (D1):Foods that make up a healthy diet. Statements: 1, 3, 5, 7, 9, 11, 13, 15, 17, 19 and 21;

Dimension 2 (D2):Building the Diet Quality Index. Statements: 2, 4, 6, 8, 10, 12, 14, 16, 18 and 20.

The query statements were organized in a Likert-type scale ${ }^{22}$ with four possible answers. Numeric values were attributed to the answers, distributed over constant intervals, from full agreement to full disagreement, through the intermediate terms inclined to agree and inclined to disagree. The numerical order could be whether descending $(4,3,2,1)$ or ascending $(1,2,3,4)$ depending on the statement being favorable or unfavorable, thus enabling the calculation of mean values and standard deviation.

Arriving at a consensus. Delphi Technique ${ }^{23,24}$ was used to implement the research instrument, and at least three of the four criteria established should be met ${ }^{25}$ :

(a) average score for each statement and for both dimensions examined, with the following interpretation:

from 1.00 to 1.99 points: consensus for disagreement;

from 2.00 to 2.99 points: lack of consensus;

from 3.00 to 4.00 points: consensus for agreement. 
Table 1. Components and score of the Diet Quality Index - Digital Food Guide (DQI-DFG). Brazil, $2013^{10}$.

\begin{tabular}{|c|c|c|c|}
\hline \multirow[t]{2}{*}{ Components } & \multirow[t]{2}{*}{ Maximum socre } & Reference value & $\begin{array}{c}\text { Reference value for } \\
\text { a score of zero }\end{array}$ \\
\hline & & \multicolumn{2}{|c|}{ (n servings/1000Kcal) } \\
\hline \multicolumn{4}{|l|}{ Moderation components ${ }^{\mathrm{a}}$} \\
\hline 1. Sugars and sweets & 10 & $\leq 0.5$ & $>0.5$ \\
\hline 2. Beef and pork & 5 & $\leq 0.5$ & $>0.5$ \\
\hline 3. Refined grains and breads & 5 & $\leq 0.5$ & $>0.5$ \\
\hline 4. Animal fat & 10 & $\leq 0.5$ & $>0.5$ \\
\hline \multicolumn{4}{|l|}{ Adequacy components $^{\mathrm{b}}$} \\
\hline 5. Poultry, seafood and eggs & 10 & $\geq 1$ & Not consumed \\
\hline 6. Whole grains and breads, tubers and roots & 10 & $\geq 2$ & Not consumed \\
\hline 7. Fruits & 10 & $\geq 1.5$ & Not consumed \\
\hline 8. Non-starchy vegetables & 10 & $\geq 2$ & Not consumed \\
\hline 9. Legumes & 5 & $\geq 1$ & Not consumed \\
\hline 10. Milk and dairy products & 10 & $\geq 0.75$ & Not consumed \\
\hline 11. Nuts & 5 & $\geq 0.25$ & Not consumed \\
\hline 12. Vegetable oils & 10 & $\geq 1$ & Not consumed \\
\hline
\end{tabular}

${ }^{\mathrm{a}}$ Dichotomus score; ${ }^{\mathrm{b}}$ Score increases with intake up to the reference standard.

(b) standard deviation: $<1,5$;

(c) frequency of agreement: at least $51 \%$ of the experts;

(d) difference between interquartile range (quartile 3 - quartile $1 /$ Q3-Q1): $<1,0$.

Experts selection. For retrieving research published from April 2010 to April 2015, the database Web of Science was consulted using the search terms healthy eating index and diet quality index, as well as Brazil as research location. Data available at the Lattes Platform were used to identify the authors with academic training in Nutrition and stricto sensu graduate studies.

Pre-test. The instrument was pre-tested by a group of five researchers, to analyze the statements' clarity and phraseology.

Instrument application. For starting the first round, the experts received an email invitation with the study casuistry and a link to access the query instrument, hosted by the QuestionPro tool. After reading an introductory text for understanding the method and agreeing with the Informed Consent Form, the invited experts had access to the instrument statements.

In starting round 2, they received the first results' consolidation. Statements for which consensus was not achieved and the experts' considerations about the open question were organized within the same Likert-type scale, with the same answer options. For both situations, each topic was accompanied by a theoretical foundation. Statements that resulted in consensus in the first round were reintroduced to the experts, so they could ratify or not their previous opinions. At the end of round 2, they received the final result of the consensus. Both the application of the two rounds and consensus emergence occurred between April and May 2015.

Study on the internal consistency of the instrument. To measure the internal consistency of the instrument, Cronbach's alpha coefficient was applied with acceptance criteria $\mathrm{R}>0.80^{8}$.

Statistical analysis. Statistical analysis was conducted from data processing using using Statistical Package for Social Sciences - SPSS software version 18 for Windows.

Ethical aspects. This study was approved by the Research Ethics Committee of the Federal University of São Paulo.

\section{Results and discussion}

Construct and theoretical reference. Theoretical foundation and construct used in the instrument design were organized into themes, as shown below:

Fresh foods: eating fresh and little processed foods is associated with a lower risk of developing cardiovascular diseases and prevention of most chronic diseases ${ }^{18}$. The application of this knowledge favors a balanced, tasty diet, which promotes a sustainable food system ${ }^{5}$.

Meat and eggs: these are important sources of protein and the recommendation is varying their 
Table 2. Themes and assertions of the instrument for the achieving the consensus on Healthy Eating and Diet Quality Index. Brazil, 2018.

\begin{tabular}{|c|c|}
\hline Themes & Assertions - Construct \\
\hline In natura foods & $\begin{array}{l}\text { 1) Healthy eating is mostly composed by food in natura. }{ }^{\text {a }} \\
\text { 7) Consuming fruits, vegetable, greenery, cereals, meat, milk and milk derivative, } \\
\text { vegetable oil and oilseeds are regularly compatible with healthy eating. }^{\text {a }}\end{array}$ \\
\hline Beef and eggs & $\begin{array}{l}\text { 2) Beef and processed meat must be classified in distinctive groups to the other meat } \\
\text { under the comprehension of a healthy eating. }{ }^{\text {a }} \\
\text { 15) A healthy eating requires the presence of either meat or eggs. }{ }^{\text {a }}\end{array}$ \\
\hline Milk and dairy products & 3) Milk and milk derivative must compose the healthy food choosing repertoire. ${ }^{a}$ \\
\hline Glycemic Index & $\begin{array}{l}\text { 4) Taking into consideration the food sugar level, potatoes are classified in the same } \\
\text { group as bread and refined cereal. }{ }^{\text {a }}\end{array}$ \\
\hline Highly palatable foods & $\begin{array}{l}\text { 5) Highly palatable food shouldn't be part of daily eating. }{ }^{\text {b }} \\
\text { 11) Sugar rich food, like soft drinks, chocolates, ice-creams or biscuits, might belong } \\
\text { to a healthy eating if their ingestion isn't usual and in small amounts. }{ }^{\text {a }} \\
\text { 12) The build criterion of a diet quality index must be stringent with highly palatable } \\
\text { food, due to the high risk of its ingestion. }{ }^{\text {a }}\end{array}$ \\
\hline Processed fats & $\begin{array}{l}\text { 6) The industrial mayonnaise production characteristics justify its classification may } \\
\text { fit better in processed fat group than in vegetable oils. }{ }^{\text {a }} \\
\text { 8) The margarine production characteristics justify that its classification may fit } \\
\text { better in vegetable oils group than in processed fat group. }{ }^{\mathrm{b}}\end{array}$ \\
\hline Source of fat in food & 9) Food rich in fat, when consumed moderately, might be part of eating. ${ }^{\text {a }}$ \\
\hline Legumes intake (beans) & $\begin{array}{l}\text { 10) It's important to consider the ingestion of beans and leguminous at Brazilian } \\
\text { eating pattern. }{ }^{\text {a }}\end{array}$ \\
\hline Nuts intake & 13) In order to keep a healthy eating, it is necessary to ingest oilseeds on a daily basis. ${ }^{b}$ \\
\hline $\begin{array}{l}\text { Purpose of the diet } \\
\text { quality index }\end{array}$ & $\begin{array}{l}\text { 14) A diet quality index, besides been an analysis tool of eating ingestion, might also } \\
\text { be used as an additional instrument to actions of food and nutritional education. }{ }^{\text {a }} \\
\text { 20) It's suitable to build a diet quality index from food groups. }{ }^{\text {a }}\end{array}$ \\
\hline $\begin{array}{l}\text { Moderation } \\
\text { components }\end{array}$ & $\begin{array}{l}\text { 16) When building a diet quality index, the moderation components are sugars, beef } \\
\text { and processed meat, processed or animal fat, refined cereals and potato. }{ }^{\text {a }}\end{array}$ \\
\hline Sugar and sweet taste & 17) Sweet beverage, even diet or light, must not compose healthy eating. ${ }^{a}$ \\
\hline Olis & $\begin{array}{l}\text { 18) The vegetable oils role about healthy justifies its inclusion among the adequacy } \\
\text { components. }{ }^{\text {a }}\end{array}$ \\
\hline $\begin{array}{l}\text { Vitamins and minerals } \\
\text { supplements }\end{array}$ & $\begin{array}{l}\text { 19) The use of vitamins supplements and minerals is a necessary strategy to ensure a } \\
\text { good nutrition. }{ }^{\text {b }}\end{array}$ \\
\hline Alchool intake & 21) The evidence about the alcohol effects in health contraindicate its ingestion. ${ }^{a}$ \\
\hline
\end{tabular}

Numerical values that indicates the answer possibilities:

a (4) Completely agree, (3) Agree in most cases, (2) Disagree in most cases, (1) Completely disagree

b (1) Completely disagree, (2) Disagree in most cases, (3) Agree in most cases, (4) Completely agree

intake ${ }^{26}$. Meat is the main source of vitamin B12, an essential nutrient for the functioning of brain and nervous systems and formation of blood cells ${ }^{19}$. However, the intake of red and processed meat is associated with the risk of developing colorectal cancer: $50 \mathrm{~g}$ of meat/day raises the risk of developing cardiovascular diseases to $30 \%{ }^{21}$. Considering the possible risks associated with the excessive consumption of these foods, quotas must be established for their intake ${ }^{10}$.

Milk and dairy products: these feature a good concentration of nutrients (proteins, vitamin A, and especially calcium), in addition to offering satiety $^{5}$. Special care should be given to sources with higher concentrations of fat (fat cheeses) ${ }^{11,17}$.

Glycemic index: a diet rich in carbohydrates, especially those with high glycemic index, is associated with obesity, type- 2 diabetes, metabolic syndrome $^{17}$ and cardiovascular diseases ${ }^{4}$. Therefore, the classification of potatoes in the "moderation components"11,17,26, in addition to refined cereals $^{4,16}$, is justified. Excessive intake of sugar raises the energy value of the diet, thus favoring weight gain, contributes to the emergence of these diseases and introduces factors related to the dependency of its consumption, increasing its intake ${ }^{15}$. 
Highly palatable foods: are those with a high content of fat, sugar, and salt, combined or not, poor in fibers and with little or no nutritional contribution $^{27,28}$. Examples include soft drinks, sugary drinks, snacks like "chips" and candy, in addition to sausages and processed meats ${ }^{27}$. These foods can also bring health risks when excessively consumed; hence, with consumption quotas and a healthy eating pattern there is the possibility of eating these foods eventually, to satisfy the palate ${ }^{17,29}$.

Processed fats: mayo and margarine are foods that provide trans fats and sodium, which, when consumed in excess, are associated with the further development of cardiovascular diseases ${ }^{5}$. For this reason, they make up the group of processed fats (moderation component), being recommended their reduced intake.

Sources of fat in the diet: a high intake of foods that are source of fats is associated with the further development of cardiovascular diseases ${ }^{5}$. However, the moderate intake of fat balances the distribution of other macronutrient $\mathrm{s}^{30}$, in addition to contributing as a source of vitamins, essential fatty acids, and minerals. The safe intake of foods from this group can also offer taste satisfaction without increased risk ${ }^{17}$.

Legumes intake (beans):rice and beans represent about a quarter of the energy consumed in the Brazilian diet ${ }^{5}$. Legumes are excellent sources of proteins, fibers, vitamins, mono-unsaturated fatty acids, and minerals ${ }^{11,17}$.

Oilseeds intake: these are excellent sources of protein, fiber, vitamins, minerals, and mono-unsaturated fatty acids ${ }^{11,17}$. Their intake may help vary the repertoire of proteins' sources to compose a diet with a lower frequency of red and processed meats, which contributes to lowering the risk of heart disease and diabetes ${ }^{14}$.

Purpose of the Diet Quality Index: monitoring and assessment of food intake can concur to healthy choices and strengthening of subject autonomy ${ }^{31}$. Indexes are auxiliary tools to assess diet quality and, thus, to facilitate the analysis of dietary intake ${ }^{7}$. To devise this Index, foods are classified into groups according to their similarity in nutritional composition and the evidence about the implications of their regular intake on health. This criterion was established aiming to emphasize foods and not nutrients ${ }^{10}$.

Sugar and sweet taste: studies on the properties that lead to sugar and sweet addiction show that the excessive intake of these foods decreases the production of ghrelin and interferes with leptin transport and signaling, thus reducing dopamine and stimulating food-related pleasure and increased intake ${ }^{15}$.

Oils: by providing essential fatty acids, oils represent a protective factor regarding cardiovascular diseases. However, their inflammatory potential should be considered for their dosage in food preparation ${ }^{11,18,19}$.

Vitamin and mineral supplements: the proper intake of fresh foods prevents most chronic diseases $^{18}$. Such effect comes from the food itself, not merely from the isolated nutrients ${ }^{5}$. Therefore, an adequate diet meets the subject nutritional needs without the need for supplements.

Alcohol intake: drinking wine is widely recognized as part of the prevention of cardiovascular diseases $^{20}$; for cancer, however, even wine is an important risk factor ${ }^{12}$. Alcohol is the most used drug worldwide; its misuse accounts for $3.2 \%$ of deaths. Another justification for not including alcohol in the Index stems from the fact that alcoholism has become both a social and public health problem in Brazil ${ }^{13}$

Study on the internal consistency of the instrument. The instrument presented good internal consistency $(\mathrm{R}=0.94)$.

Consultations with experts. Although the dimensions "Healthy Eating" and "Diet Quality Index" deal with frequent topics of the participants' expertise, and even though the $\mathrm{GAPB}^{5}$ has just recently re-stimulated the discussion on "Healthy Eating", two rounds were required to achieve a consensus.

Of the 54 experts selected and invited into the study, $30 \%$ agreed to participate, being $88 \%$ of them affiliated with public institutions, regionally distributed as follows: $6 \%$ in the Northeast, $18 \%$ in the Midwest, 38\% from Southeast and $38 \%$ in the South. All the researchers work on the theme of Healthy Eating for at least four years (56\% between four and 10 years, $19 \%$ from 11 to 20 years, and $25 \%$ between 20 and 30 years); $41 \%$ of them classified their own experience on the subject as proper qualification and $59 \%$ as highly qualified. Regarding the dimension Diet Quality Index, 50\% reported having experience between 6 and 10 years, 38\% had from 2 to 5 years of experience, $6 \%$ had only 1 year and $6 \%$ did not respond; $13 \%$ identified their condition as highly qualified, $75 \%$ considered they had proper qualification and $12 \%$ declared to have inappropriate qualification. These data show homogeneity among the research participants regarding domain over the subjects under study. Of the 16 
experts who responded to round 1, $10(63 \%)$ continued to round 2. According to Giannarou \& Zervas $^{25}$, a sample between 10 and 15 participants with these characteristics can produce sufficient results.

1st round. In a comprehensive analysis, both Dimensions examined reached a consensus with an average of 3.02 points $(S D=0.67)$ and 3.43 points $(\mathrm{SD}=0.31)$ for Dimensions 1 and 2, respectively. Table 3 shows the results of the analysis used to arrive at a consensus for Dimensions 1 and 2, respectively, at each round. All statements of $\mathrm{D} 2$ reached consensus, unlike $\mathrm{D} 1$, where three statements did not complete at least three of the four criteria adopted in this study (statements 5, 13, and 15). Assertions that have not reached consensus were reintroduced to the experts in the 2nd round, with the corresponding theoretical foundation.

2nd round. Both dimensions examined reached a consensus with an average of 3.18 points $(\mathrm{SD}=0.62)$ for $\mathrm{D} 1$ and 3,27 points $(\mathrm{SD}$ $=0.9$ ) for D2. As shown in Table 3, the statement "Highly palatable foods cannot be part of the daily diet" (statement 5) did not achieve a consensus even after the theoretical foundation was presented. Despite the understanding that they lead to health risks when excessively eaten, the possibility to use this foods for eventual satisfaction may have motivated such result. Effects such as the stimulus to addiction behaviors ${ }^{28}$ and the displacement of high nutritional density foods, leading to low diet quality ${ }^{27}$, justify the proposition of this statement. However, even the proposal "Foods high in sugar - sodas, chocolates, ice cream or cookies, may be part of a healthy diet if their intake is not frequent and in small amounts" (statement 11) did not achieve consensus. This topic, however, is resumed in the open question, which indicates it caused doubts among the experts. Thus, a theoretical foundation was elaborated to respond the doubts posed, so it was possible to arrive at a consensus on the theme.

Meats, eggs and oilseeds are relevant protein sources and provide mineral micronutrients and vitamin $\mathrm{B} 12^{17,26}$. This understanding justifies the statement "a healthy diet requires the presence of meats or eggs" (statement 15) ${ }^{19}$. Nevertheless, considering that the consumption of red and processed meats is associated with the risk of developing colorectal cancer ${ }^{21}$, the approach expressed in "a healthy diet requires daily intake of oilseeds" (statement 13) becomes relevant due to its nutritional composition and the possibility of diversifying protein sources in the $\operatorname{diet}^{17}$. Thus, consensus was achieved for both statements, which is also represented by the descriptive level of response patterns comparison between first and second rounds.

Open question. Suggestions from experts in response to the open question generated 11 discussion topics. Table 4 presents the results of analyses employed for these topics - all reached consensus in accordance with the criteria established in this study.

Among the topics brought by experts, we considered that "Classification of potato according to glycemic index", "Alcohol intake", and "Purpose of Diet Quality Index" are included in the design of the analysis instrument. Although consensus was reached in the first round for all these topics, when they were reintroduced in the open question a theoretical foundation was elaborated to reinforce the response to these manifestations. For the other themes proposed by the experts, the following arguments were presented (emphasis added):

Processed foods (must be considered) as components of the diet quality index

Index components that include meats and fats are classified as "moderation" and are built with a subclass for processed foods. Other foods such as cookies, sugary drinks, snacks like chips and candy are also classified as "moderation components", for which the recommended intake is limited to small quantities 4 . For the food group "milk and dairy products", am adjustment to the Index is required to include sugary yogurt and dairy drinks. Such design is in line with the guidelines proposed by the GAPB, which supports the identification of foods according to their degree of processing, especially the message "avoid the consumption of ultra-processed foods".

Sodium and foods rich in trans fats and/or cholesterol (must be considered) as components of the diet quality index

The option for focusing on foods - and not nutrients - guided the organization of the Index into groups divided by nutritional composition similarity according to evidence about impacts of its regular intake on health. Thus, aliments with high sodium concentration are included in the subclass of processed foods. Foods that are 
Table 3. Results to determine the consensus and descriptive level from the comparison of the pattern of responses in the 1st and 2nd rounds on Dimensions 1 and 2 from the average, standard deviation, frequency for agreement and interquartile range (Quartile 3 - Quartile 1/ Q3-Q1). Brazil, 2018.

\begin{tabular}{|c|c|c|c|c|c|c|c|c|c|}
\hline \multirow[t]{2}{*}{ Statements } & \multicolumn{2}{|c|}{ Average } & \multicolumn{2}{|c|}{$\begin{array}{l}\text { Standard } \\
\text { deviation }\end{array}$} & \multicolumn{2}{|c|}{$\begin{array}{l}\text { Frequency for } \\
\text { agreement (\%) }\end{array}$} & \multicolumn{2}{|c|}{ Q3-Q1 } & \multirow[t]{2}{*}{$\mathbf{p}$} \\
\hline & $1^{\mathrm{a}}$ & $2^{a}$ & $\mathbf{1}^{\mathrm{a}}$ & $2^{\mathrm{a}}$ & $1^{\mathrm{a}}$ & $2^{\mathrm{a}}$ & $1^{\mathrm{a}}$ & $2^{\mathbf{a}}$ & \\
\hline \multicolumn{10}{|c|}{ Dimension 1: Foods that make up a healthy diet } \\
\hline 1 & 3.69 & 3.80 & 0.48 & 0.42 & 100.00 & 100.00 & 1.00 & 0.00 & 0.801 \\
\hline 3 & 3.63 & 3.70 & 0.50 & 0.48 & 100.00 & 100.00 & 1.00 & 0.75 & 0.172 \\
\hline 5 & $1.81^{\mathrm{a}}$ & $1.40^{\mathrm{a}}$ & 0.98 & 0.52 & $12.50^{\mathrm{a}}$ & $0.00^{\mathrm{a}}$ & 1.00 & 1.00 & 0.019 \\
\hline 7 & 3.56 & 4.00 & 0.51 & 0.00 & 100.00 & 100.00 & 1.00 & 0.00 & 0.284 \\
\hline 9 & 3.25 & 3.50 & 0.86 & 0.71 & 75.00 & 90.00 & $1.25^{\mathrm{a}}$ & 1.00 & 0.172 \\
\hline 11 & 3.19 & $2.50^{\mathrm{a}}$ & 0.66 & 1.18 & 87.50 & 60.00 & 1.00 & $1.75^{\mathrm{a}}$ & 0.046 \\
\hline 13 & $2.31^{\mathrm{a}}$ & $2.90^{\mathrm{a}}$ & 0.70 & 0.57 & $31.2^{\mathrm{a}}$ & 80.00 & 1.00 & 0.00 & 0.008 \\
\hline 15 & $2.00^{\mathrm{a}}$ & 3.10 & 0.97 & 0.88 & $18.75^{a}$ & 70.00 & 1.00 & $1.75^{\mathrm{a}}$ & 0.038 \\
\hline 17 & 3.63 & 3.70 & 0.50 & 0.48 & 100.00 & 100.00 & 1.00 & 0.75 & 0.513 \\
\hline 19 & 3.06 & $2.80^{\mathrm{a}}$ & 0.68 & 0.79 & 81.25 & 60.00 & 0.25 & 1.00 & 0.247 \\
\hline 21 & 3.06 & $2.90^{\mathrm{a}}$ & 0.93 & 0.88 & 75.00 & 80.00 & $1.25^{\mathrm{a}}$ & 0.00 & 0.300 \\
\hline \multicolumn{10}{|c|}{ Dimension 2: Building the Diet Quality Index } \\
\hline 2 & 3.31 & 3.50 & 0.70 & 0.71 & 87.50 & 90.00 & 1.00 & 1.00 & 0.262 \\
\hline 4 & 3.06 & 3.60 & 0.93 & 0.97 & 75.00 & 90.00 & 1.25 & 0.00 & 0.072 \\
\hline 6 & 3.81 & 4.00 & 0.54 & 0.00 & 93.75 & 100.00 & 0.00 & 0.00 & 0.392 \\
\hline 8 & 3.44 & 3.90 & 0.81 & 0.32 & 93.75 & 100.00 & 1.00 & 0.00 & 0.393 \\
\hline 10 & 4.00 & 4.00 & 0.00 & 0.00 & 100.00 & 100.00 & 0.00 & 0.00 & 0.424 \\
\hline 12 & 3.38 & 3.90 & 0.72 & 0.32 & 87.50 & 100.00 & 1.00 & 0.00 & 0.223 \\
\hline 14 & 3.69 & 3.80 & 0.48 & 0.42 & 100.00 & 100.00 & 1.00 & 0.00 & 0.223 \\
\hline 16 & 3.06 & 3.80 & 1.00 & 0.42 & 81.25 & 100.00 & 1.00 & 0.00 & 0.368 \\
\hline 18 & 3.25 & 3.60 & 0.58 & 0.70 & 93.75 & 90.00 & 1.00 & 0.75 & 0.050 \\
\hline 20 & 3.31 & 3.60 & 0.60 & 0.52 & 93.75 & 100.00 & 1.00 & 1.00 & 0.506 \\
\hline
\end{tabular}

Table 4. Results of the themes generated in the open question ${ }^{\mathrm{a}}$ about Dimensions 1 and 2 from the average, standard deviation (SD), percentage of frequency for agreement and interquartile range difference (Quartile 3 Quartile 1/ Q3-Q1). Brazil, 2018.

\begin{tabular}{|c|c|c|c|c|}
\hline Theme proposed by specialists & Average & SD & $\begin{array}{c}\text { Frequency of } \\
\text { agreement } \\
(\%)\end{array}$ & Q3-Q1 \\
\hline \multicolumn{5}{|l|}{ Dimension 1: Foods that make up a healthy diet } \\
\hline Characterization of highly palatable foods & 3.70 & 0.48 & 100.00 & 0.75 \\
\hline Gluten as a relevant topic & 3.30 & 1.25 & 80.00 & 0.75 \\
\hline Frequency of meals & 3.20 & 1.14 & 70.00 & $1.75^{\mathrm{c}}$ \\
\hline Alchool intake & 3.70 & 0.67 & 90.00 & 0.00 \\
\hline Nutrient density of food & 3.80 & 0.42 & 100.00 & 0.00 \\
\hline \multicolumn{5}{|l|}{ Dimension 2: Building the Diet Quality Index } \\
\hline Processed food as components of DQI ${ }^{\mathrm{b}}$ & 3.40 & 0.97 & 90.00 & $1.00^{\mathrm{c}}$ \\
\hline Sodium as components of DQI ${ }^{\mathrm{b}}$ & 3.40 & 0.70 & 90.00 & $1.00^{\mathrm{c}}$ \\
\hline $\begin{array}{l}\text { Foods rich in trans fats and / or cholesterol as components } \\
\text { of DQI }{ }^{\mathrm{b}}\end{array}$ & 3.80 & 0.42 & 100.00 & 0.00 \\
\hline Classification of potatoes according to the glycemic index & 3.30 & 0.95 & 90.00 & $1.00^{\mathrm{c}}$ \\
\hline Prupose of Dieta quality Index & 3.80 & 0.42 & 100.00 & 0.00 \\
\hline
\end{tabular}


source of trans fat and/or cholesterol are covered by groups "red and processed meats", "animal and processed fats", and "milk and dairy products". Trans fats also include formulations of products under the group "sugar and sweets" in aliments such as cookies and ice cream, among others. Thus, the experts' suggestions are satisfied.

\section{Gluten as a relevant topic}

Eliminating gluten from the diet is indicated when confirmed the diagnosis of coeliac disease, dermatitis herpetiformis, allergy or sensitivity to gluten. Considering that this Index is meant for the healthy population, a component about gluten was not proposed ${ }^{32}$.

(How to include in the IQD) food and nutritional appeals: fortified, diet, and light

The Index elaboration was based on the emphasis to foods and not nutrients, and the groups were generated by nutritional composition similarity and implications of the regular intake on health. Thus, the diversity of modified foods (enriched or with functional claims, diet and light) makes the grouping complex.

High intake of sweet aliments leads to action that create dependency through the reduction of dopamine and consequent pleasure stimulation $^{15,16}$. Therefore, these foods are grouped with sugars and candies, included into moderation components, so that the intake is reduced.

\section{Meal frequency}

There is no evidence about any benefit of food intake fractionation to create a guideline on the appropriate number of meals per day ${ }^{5,14}$.

\section{Nutritional density of the foods}

The organization of "adequacy components" is based on the nutritional contribution of the foods it comprises. Such components ensure the supply of nutrients to meet nutritional needs, as well as bioactive compounds. They are, therefore, high nutritional density foods ${ }^{10}$.
"Alcohol" is addressed for in the statement 21 , being a consensus on both rounds, including in the theoretical foundation presented for the open question. The justification that drinking wine favors the prevention of cardiovascular diseases $^{20}$, as well as the absence of this information in the current $\mathrm{GAPB}^{5}$ could have hindered the arrival at this consensus. Nonetheless, the consensus on not including alcohol as a component to a healthy diet was achieve due to the fact this drug is a risk factor for cancer ${ }^{12}$ and its misuse has become a social and public health problem ${ }^{13}$.

\section{Conclusion}

The combined application of Likert method and Delphi technique enables the arrival at a consensus on Healthy Eating, with the recommendation of the following markers of diet quality: "fresh foods", "fruits", "vegetables", "milk and dairy products" and "legumes". "Processed and readyto-eat foods", "excessive sweets and fats", "supplements" and "alcohol" were identified as risk factors. The importance given to legumes and the construct that supports the non-inclusion of alcohol as part of a healthy diet are original components of the DQI-DFG and are among the main contributions of this study, unparalleled for querying Brazilian experts for this purpose. In spite of this fact, analysis on the Index application results in different contexts may point improvements that overcome any study limitations. Among the weaknesses of the Index devising process, the most important are the absence of the indication of weekly consumption components - which can by suitable for bovine and porcine meats, and the lack of cooking techniques as risk markers for diet quality.

Each of the variables of analysis that contribute for the construction of healthy food profile in the form of a Diet Quality Index should express the best understanding possible from evidence of food and nutrition fields, incorporating dimensions associated with the eating ritual and sustainable food systems. Thus, renewing consensus about major issues concerning healthy eating may help improving Diet Quality Indexes. 


\section{Collaborations}

SA Caivano and SMA Domene participated in the design, planning, analysis, interpretation and writing of the article.

\section{Acknowledgments}

We thank the researchers who contributed to the pilot testing of this study: Daniela Silva Canella, Lia Thieme Oikawa Zangirolani, Maria Angélica Tavares de Medeiros, and Rosa Wanda Diez Garcia. Also, we acknowledge the researchers who made possible a consensus.

\section{References}

1. World Health Organization (WHO). Assessing national capacity for the prevention and control of noncommunicable diseases: report of the 2010 global survey. Geneva: WHO; 2012.

2. Dobbs R, Sawers C, Thompson F, Manyika J, Woetzel J, Cild P. Overcoming obesity: An initial economic analysis. London: McKinsey Global Institute; 2014.

3. Brasil. Ministério da Saúde (MS). POF - Pesquisa de Orçamentos Familiares 2008-2009: Avaliação Nutricional da disponibilidade de alimentos no Brasil. Brasília: MS; 2010.

4. Katz DL, Meller S. Can we say what diet is best for health? Annu Rev Public Health. 2014; 35:83-103.

5. Brasil. Ministério da Saúde (MS). Guia alimentar para a população brasileira. Brasília: MS; 2014.

6. Philippi ST, Latterza AR, Cruz ATR, Ribeiro LC. Pirâmide alimentar adaptada: guia para escolha dos alimentos. Rev Nutr 1999; 12(3):65-80.

7. Jaime PC, Bandoni DH, Duran ACFL, Fisberg RM. Diet quality index adjusted for energy requirements in adults. Cad Saude Publica 2010; 26(11):2121-2128.

8. Guenther PM, Kirkpatrick SI, Reedy J, Krebs-Smith SM, Buckman DW, Dodd KW, Casavale KO, Carroll RJ. The Healthy Eating Index-2010 is a valid and reliable measure of diet quality according to the 2010 Dietary Guidelines for Americans. J Nutr 2014; 144(3):399-407.

9. Andrade SC, Previdelli AN, Marchioni DML, Fisberg RM. Avaliação da confiabilidade e validade do Índice de Qualidade da Dieta Revisado. Rev Saude Publica 2013; 47(4):675-683.

10. Caivano S, Domene SMA. Diet quality index for healthy food choices. Rev Nutr 2013; 26(6):693-699.

11. Willett W. Eat, drink, and be healthy: the Harvard Medical School guide to healthy eating. New York: Simon and Schuster; 2011.

12. Brenner H, Kloor M, Pox CP. Colorectal cancer. Lancet 2014; 383(9927):1490-1502.

13. Laranjeira R, Pinsky I, Zaleski M, Caetano R, Duarte P. I Levantamento nacional sobre os padrões de consumo de álcool na população brasileira. Brasília. Secretaria Nacional Antidrogas; 2007.

14. Leidy HJ, Campbell WW. The effect of eating frequency on appetite control and food intake: brief synopsis of controlled feeding studies. J Nutr 2011; 141(1):154157.

15. Lustig RH, Schmidt LA, Brindis CD. The toxic truth about sugar. Nature 2012; 482(7383):27-29.

16. Santos FL, Esteves SS, Pereira AC, Yancy Junior WS, Nunes JPL. Systematic review and meta-analysis of clinical trials of the effects of low carbohydrate diets on cardiovascular risk factors. Obes Rev 2012; 13(11):1048-1066.

17. Harvard School of Public Health (HSPH). Harvard researchers launch Healthy Eating Plate. Chan School of Public Health [Internet]. 2011 [citado 2012 Aug 18]. Available at: https://www.hsph.harvard.edu/news/ press-releases/healthy-eating-plate/

18. Bonaccio M, Iacoviello L, de Gaetano G, Investigators M-S. The Mediterranean diet: the reasons for a success. Thromb Res 2012; 129(3):401-404. 
19. Institute of Medicine (IOM). Dietary Reference Intakes for vitamin $C$, vitamin $E$, selenium, and carotenoids. Washington: The National Academies Press; 2000.

20. Martínez-González MA, Sanchez-Villegas A. Review: The emerging role of Mediterranean diets in cardiovascular epidemiology: Monounsaturated fats, olive oil, red wine or the whole pattern? Eur J Epidemiol 2004; 19(1):9-13.

21. World Cancer Research Fund. American Institute for Cancer Research (AICR). Physical activity and the prevention of cancer: a global perspective. Washington: AICR; 2007.

22. Wakita T, Ueshima N, Noguchi H. Psychological distance between categories in the Likert Scale: comparing different numbers of options. Educ Psychol Meas 2012; 72(4):533-546.

23. Rowe G, Wright G. The Delphi technique as a forecasting tool: issues and analysis. Int J Forecast 1999; 15(4):353-75.

24. Wright JTC, Giovinazzo RA. Delphi: uma ferramenta de apoio ao planejamento prospectivo. Cad Pesqui em Adm 2000; 1(12):54-65.

25. Giannarou L, Zervas E. Using Delphi technique to build consensus in practice. Int J Bus Sci Appl Manag 2014; 9(2):65-82.

26. Bach-faig A, Berry EM, Lairon D, Reguant J, Trichopoulou A, Dernini S, et al. Mediterranean diet pyramid today. Science and cultural updates. Public Health Nutr 2011; 14(12A):2274-2284.

27. Martins APB, Levy RB, Claro RM, Moubarac JC, Monteiro CA. Increased contribution of ultra-processed food products in the Brazilian diet (1987-2009). Rev Saude Publica. 2013; 47(4):656-665.
28. Parylak SL, Koob GF, Zorrilla EP. The dark side of food addiction. Physiol Behav 2011; 104(1):149-156.

29. Viana MR, Neves AS, Camargo Junior KR, Prado SD, Mendonça ALO. A racionalidade nutricional e sua influência na medicalização da comida no Brasil. Cien Saude Colet 2017; 22(2):446-456.

30. Katan MB, Brouwer IA, Clarke R, Geleijnse JM, Mensink RP. Saturated fat and heart disease. Am J Clin Nutr 2010; 92(2):459-460.

31. World Health Organization (WHO). Expert Consultation on Diet, Nutrition and the Prevention of Chronic Diseases. Diet, nutrition, and the prevention of chronic disease: Report of a joint WHO/FAO expert consultation. Geneva: WHO; 2003.

32. Elli L, Roncoroni L, Bardella MT. Non-celiac gluten sensitivity: Time for sifting the grain. World J Gastroenterol 2015; 21(27):8221-8226.

Article submitted 09/04/2018

Approved 11/10/2018

Final version submitted 13/10/2018 


\section{ERRATA}

p. 2551

onde se lê:

Simone dos Anjos Caivano (https://orcid.org/0000-0002-3035-9888) ${ }^{1}$

Semíramis Martins Álvares Domene (https://orcid.org/0000-0003-3003-2153) ${ }^{1}$

leia-se:

Simone dos Anjos Caivano (https://orcid.org/0000-0002-3035-9888) ${ }^{1}$

Semíramis Martins Álvares Domene (https://orcid.org/0000-0003-3003-2153) ${ }^{2}$

onde se lê:

${ }^{1}$ Universidade Metropolitana de Santos. Av. Conselheiro Nébias 536, Encruzilhada. 11045-002

Santos SP Brasil. simone.caivano@hotmail.com

\section{leia-se:}

${ }^{1}$ Universidade Metropolitana de Santos. Av. Conselheiro Nébias 536,

Encruzilhada.11045-002 Santos SP Brasil.simone.caivano@hotmail.com

${ }^{2}$ Departamento de Políticas Públicas e Saúde Coletiva, Universidade Federal de São Paulo. Santos SP Brasil. 